\title{
Endo-referência de uma ciência formalizada da natureza
}

\section{MICHEL PATY}

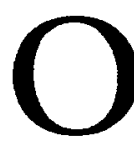

problema que gostaríamos de abordar neste trabalho diz respeito à significação das proposiçóes de uma ciência da natureza no momento $\mathrm{cm}$ que ela atinge um alto grau de formalizaçáo $\mathrm{e}$ abstraçáo. Tal como, por exemplo, hoje em dia, a teoria física, quer se trate da relatividade geral ou da física quântica. Apesar de serem de natureza muito abstrata e formal, os princípios, os conceitos e, de modo geral, os cnunciados que constituem essa teoria não têm outro papel senão o de fornecer, por essa representação, uma inteligibilidade do mundo físico exterior (o que chamaremos de realidade física, qualquer que scja a compreensão que tenhamos deste termo). Todavia, por sua natureza formal, esses enunciados apenas têm sentido pcla estrutura do sistema teórico no qual se inserem.

Parecc existirem aí dois pressupostos ou propriedades em oposição, senāo contraditórios. De um lado, a teoria que daria, na transparência quase axiomática dos enunciados, o sentido deles próprios (isto é, seu conterido, neste caso scu conterido físico). De outro lado, se o conteúdo tem como objeto a natureza (no caso do nosso interesse, a realidade física), está ligado a dados de experiência (assim sendo, pode ser chamado de empírico), c não pode ser relatado apenas por uma estrutura formal. Os enunciados de uma ciência teórica de conteúdo empírico implicam, portanto, uma tensão entre o caráter formal e o conteúdo, rcferindo-sc este à nccessidade do real. Esta, porém, não se manifesta dirctamcnte, e apenas temos acesso à realidade física através da experiência que cla mesma demanda para ser interpretada segundo a mediação de proposiçôes teóricas (formalizadas).

Em relaçĩo às significaçõos que conferem a inteligibilidade, seria possível mantermos o caráter referencial da teoria a respeito de suas proposiçóes ou deveríamos abandoná-lo em prol de outras instâncias sus- 
cetíveis de conferir o sentido do conteúdo (como, por exemplo, a linguagem ou a experiência)?

O problema é semelhante àquele da oposição entre o formal matemático e o rcal físico que Einstein exprimia nestes termos: "Na medida em que as teorias matemáticas se aplicam à realidade, elas não são infalíveis; e, na medida em que são infalíveis, não se aplicam à realidade" (1). Transcrita em termos kantianos, como o propôs Carnap, assim se leria a oposição: "Na medida em que a matemática é sintética, não é a priori; na medida em que ela é a priori, náo é sintética" (2). Em relação à inteligibilidade kantiana, a ligação, a priori e do sintético, condição de possibilidade, por exemplo, da geometria como ciência, é desfeita pela diferenciação entre a geometria pura ou axiomática e a geometria prática, ou geometria física.

De modo geral, a dissociação dos dois termos da expressão sintético a prioricompreendida no sentido estrito de Kant torna aparente a questāo da relação entre o formal (que ressaltaria o a priori) e o conteúdo (sintético, e a posteriori). Essa questáo obtém do empirismo uma resposta clara: a da dissolução pura e simples do sintético a priori e da impossibilidade de uma solução racionalista. A referência da representação teórica está, então, inteiramente na experiência, e a significação das proposiçóes simplesmente ligada à sua possibilidade de verificação experimental.

Portanto, a teoria formalizada (por uma ciência de conteúdo empírico) mal se ajusta à posição empirista, que não faz suficientemente jus ao caráter verdadeiramente cognitivo das proposiçóes teóricas e que coloca de maneira insatisfatória a questáo dos conteúdos e das significaçóes. Curiosamente, por mais empirista que se pretenda, essa concepção se fundamenta em uma visão da ciência mais idealmente. reconstruída que real e em uma acepçáo logicista da noção de teoria. Vejamos então, para começar, o que se deve compreender por teoria formalizada no caso de uma ciência como a física.

\section{Teoria formalizada e ciência da natureza}

A mecânica de Newton, a termodinâmica, a teoria eletromagnética de Maxwell, a teoria da relatividade restrita, a relatividade geral, a mecânica quântica, a teoria quântica dos campos, a cosmologia, são todas, em maior ou menor grau, teorias formalizadas concernentes a uma ciência da natureza, a física. Ainda que correspondam a conterídos emptricos, determinados graças ao recurso da experiência ou da observaçáo, cons- 
tituem sistemas hipotético-dedutivos de formulação abstrata e muito distantes das experiências dos sentidos. Esses sistemas, de estrutura lógico-matemática, compreendem princípios básicos e normativos, conceitos associados a grandezas físicas representadas simbolicamente por entidades matemáticas e regidas por princípios e regras de correspondência entre essas grandezas e os fenômenos que se podem observar e ser medidos (podendo a correspondência ser indireta e por meio de grandezas matemáticas auxiliares).

Um sistema dessa natureza se caracteriza por uma grande transparência na dedução e por uma opacidade nos princípios e nos elementos (conceitos, relaçôes entre conceitos, constantes e valores de determinação apenas empíricos que figuram nas equaçóes) (3) que servem como ingredientes na construçáo formal $\mathrm{e}$ que encerram o conterido fisico. Podemos pensar que é nessa opacidade que reside o caráter irredutivelmente real (exterior ao pensamento e à sua reconstruçáo de tipo axiomático) do que descreve a teoria, ou seja, de seu objeto. Podemos igualmente estimar que movimento em direção à formalização das teorias é aquele de uma complexidade inicial (da estrutura e dos elementos opacos que ela reúne) em direção a maior simplicidade, ou seja, em direçáo a uma transparência advinda do conjunto: simplicidade não da teoria matemática subjacente à estrutura, mas do próprio objeto tal como é descrito (4).

Precisamos nos deter um pouco na noção de objeto de uma ciência ou de

\section{Filosofia da ciencia}

Quando, em dezembro p.p., fui incumbido pelo IEA de apresentar o professor Michel Paty, recordaçóes de fatos ocorridos há quase meio século me ocorreram. Corria o início da década dos 50, precisamente o ano de 1952 , quando, creio eu, pela primeira vez no Brasil foi ministrado na antiga Faculdade Nacional de Filosofia, da Universidade do Brasil, pelo professor René Poirier, um curso sob o título de "Filosofia da Natureza" abordando alguns temas hoje incluídos nos currículos de filosofia da ciência. $O$ curso deveu-se à iniciativa do professor Plínio Rocha, que várias vezes nos falou da atualidade dos temas tratados por Poirier e, segundo sua visáo, do lugar que deveriam ocupar no cenário de nossa cultura em futuro próximo. Poucos dias antes de sua primeira palestra eu conversei informalmente com Paty. Ele falava com entusiasmo do trabalho de vários de seus orientandos da USP e do grau de interesse que a filosofia da ciência desperta nos jovens de hoje. Constatei entăo que Plínio Rocha estava certo em suas profecias...

* Lafayette de Morres é coordenador do Grupo de Lógica e Teoria da Ciéncia do IEA-USP. 
uma teoria e no que o caracteriza no âmbito uma ciência formalizada (sua definiçâoo lógica, sua relação com os fatos). Por objeto de uma teoria, entendemos o que ela descreve (e se propóe descrever) através de suas proposiçóes: um conjunto de fenômenos ou de propriedades. $O$ objeto está em posição de relação lógica com a teoria e a definição deles é recíproca. Falamos de teoria quando designamos as modalidades da descrição ou de seu objeto, quando nos restringimos aos fenômenos e propriedades a se descrever. Não há identificação do objeto com a teoria, mas, sim, adequação. A diferença de natureza entre os dois, que intuitivamente presumimos, é difícil de ser formulada, já que o objeto, como fenômenos e propriedades, apenas pode ser pensado através de conceitos e relaçóes de conceitos que, aliás, correspondem aos mesmos da teoria (sendo essa equivalência tanto mais estreita quanto for elevado o estado de formalização).

Intuitivamente, o cientista relaciona o objeto visado e descrito na natureza, ou realidade, exterior ao próprio pensamento. Porém, é obrigado, desde que queira designá-lo de modo mais preciso, a recorrer a elementos conceituais: o pensamento não tem acesso imediato à realidade, e a experiência the fornece apenas uma abordagem indireta, uma vez que recorre a esse mesmo pensamento para ser esclarecida, decifrada e até definida. É assim que o próprio objeto (no sentido que aqui consideramos, objeto de uma ciência ou de uma teoria) é, previamente à sua apreensão, submetido a uma definição, a uma simplificação (na complexidade dos dados de experiências, que remontam aos dos sentidos), a uma restriçấo que o qualifica mental e logicamente. É o caso de qualquer objeto de uma representação, inclusive no conhecimento comum. A cada etapa, em qualquer área, o objeto de nossas descriçóes é definido por uma relaçáo de equivalência que o delimita. Conhecemos os clássicos exemplos do Sol de toda manhã, suposto ser o mesmo, ou da estrela da manhã e da noite, que se identifica ao planeta Vênus. Ou ainda, os fenômenos elétricos ou magnéticos que se distinguem dos outros e se identificam segundo suas características. A relaçáo de equivalência que os determina está evidentemente ligada às noçóes de identidade, de permanência e a outras categorias necessárias para qualificar os objetos mais complexos. Os fenômenos eletromagnéticos, o átomo, a radiação, os fenômenos quânticos apenas o são porque um filtro mental ( $e$, a princípio, sensorial) os identifica e os separa.

Cada um dos elementos que contribui para formar uma representação destaca-se baseado em possibilidades múltiplas, como conseqüência de uma seleção mental, de uma escolha, que corresponde à definição do objeto lógico em relação à teoria. Invoquemos a expressiva analogia 
da necessidade de utilizar um diafragma para obter a imagem óptica de um objeto (sem diafragma, os raios enviados pelo objeto em todos os sentidos são incoerentes e não forneceriam imagem). $O$ mesmo ocorre no caso do objeto conceitual, o pensamento impóe seu próprio diafragma limitando os dados (por exemplo, as impressóes dos sentidos), selecionando-os de forma direcional; é assim que chega a se formar uma imagem como no quarto escuro que reproduz o objeto (modificando-o). Qualquer definição de um objeto supóe necessariamente a imposiçăo de um elemento fornecido pelo pensamento, correlativo de uma escolha em relaçấo à natureza de nossa representação.

Essa operação de identificação e de separação (que é ainda uma relaçáo de equivalência) prepara, por assim dizer, o objeto para as determinaçóes de teoria através da qual nos propomos descrevê-lo. Porém, ao mesmo tempo, vemos que o objeto das ciências da natureza (das ciências não puramente formais, de conteúdo empírico) não é unicamente definido por essa convenção através da qual escolhemos uma relação de equivalência (pois ć uma convenção, apesar de participar de uma elaboração que a relacione à experiência). Não é apenas o objeto lógico da teoria: colocado $\mathrm{cm}$ relação a algumas outras consideraçóes, umas anteriores à definiçâo lógica acima, outras posteriores a ela, e das quais se pode dizer, para resumir, que se referem a uma elaboração ou construção e uma prática.

Antes da caracterização teórica que se dedica a descrever esse objeto lógico, intervém o conhecimento dado dos fenômenos a partir da experiência. Esta, porém, é considerada nesse estágio não tanto sob as espécies de uma experiência específica quanto como um conjunto de experiências unidas entre si, concordantes, revelando uma ordem (de certo tipo de fenômenos), $\mathrm{c}$ já inteligíveis em certo grau através de um esquema conceitual e teórico anterior.

Em seguida, após precisar a definiçâo do objeto a ser descrito, vem a elaboração teórica e conceitual, que é construçāo e reorganização, e que inclui a interpretação das grandezas e das proposiçóes que as unem, ou seja, o enunciado desses fatos; a seguir, novamente intervém a experiência que, desta vez, pode ser específica, pela sua relação com a predição do esquema teórico, e cujos resultados servem como teste.

Antes e depois do pensar sobre a teoria e seu objeto em sua relação (lógica) de adequação, ou seja, nos momentos que acabamos de indicar, surge o problema da referência, que assim pode ser enunciado: a que relacionamos os enunciados ou proposiçóes que, tomados no seu conjunto, constituem a teoria cujo objeto gostaríamos que ela descrevesse, 
o objeto oposto, porém, de certa forma, igualmente dado (pelos processos anterior $e$ posterior à definiçăo lógica)? O problema da referência da teoria está ligado à natureza do objeto, não apenas por sua relação lógica, visto que é objeto elaborado e construído, e se revela em sua própria elaboração. Essa consideraçăo é suficiente para mostrar que a teoria não pode se referir a'seu objeto enquanto objeto lógico, isto é, que nāo pode ser auto-referencial. Não obstante, vimos que a teoria enquanto sistema participa, até certo ponto, da referência de suas proposiçóes.

Para sair do imbróglio, é preciso adotar uma tese sobre a natureza do objeto. Através de sucessivas reduçóes em cada etapa do conhecimento, admitiremos que ele se refere inicialmente a um estado de coisas que preexiste à sua definição lógica (mas o qual talvez jamais alcançaremos, mesmo levado ao estágio rudimentar das impressóes dos sentidos). Do mesmo modo, posteriormente às evoluçóes desse objeto, que são também as de suas sucessivas descriçōes e de suas mudanças de qualificação (o objeto se modifica com as teorias que the correspondem), a teoria tenta escapar àquilo que a última análise lógica ainda contém de convencional, depois de tantas abstraçōes sucessivas, tendo despojado, cada vez mais, de qualidades opacas à formalizaçăo matemática. Que ela jamais consiga náo significa que o objeto-alvo, da teoria permaneça encerrado em uma sucessão de operaçóes apenas lógicas.

De certa forma, uma relação lógica de definição recíproca une o objeto da teoria a ela, tanto quanto consideramos esta estrutura, ele é também um objeto- alvo cuja característica é perceptível no movimento da evolução teórica. Esse movimento de transformação, que apela para elementos indissociavelmente teóricos ou formais e experimentais, resulta de um determinação que foge ao âmbito da lógica, consideraçóes unicamente sobre a estrutura.

A mais natural, intuitiva e simples posição, que parece sugerida por esse estado de coisas, é colocar, tanto na origem como no fim do processo de conhecimento (ambos extrapolados de uma série finita de momentos de evolução), uma exterioridade em relação às operações mentais (e, em particular, às operaçóes lógicas e formais) da conceituação teórica. É essa exterioridade que consideraremos como realidade (por exemplo, realidade física, ou biológica, etc.). Mesmo que não se apreenda essa exterioridade como tal, e que, por razóes já citadas, possamos apenas postular essa mesma realidade, em nada retira a necessidade de levá-la em consideração. Resta-nos, entretanto, a dificuldade, que não é pequena, de considerá-la, sem poder descrevê-la, mas, para tanto, sem rela- 
cioná-la imediatamente a consideraçóes ontológicas ou metafísicas: dito de outra forma, encontrar para ela um substituto epistemológico suscetível de preencher sua função em relação à própria teoria (por cxemplo, física).

\section{Inteligibilidade e significação}

Examinemos agora o que entendemos por inteligibilidade (dos fenômenos, ou do mundo) e por significação (das proposiçốcs), questôes que condicionam diretamente a interpretação da teoria e o problema de sua referencia. Antes de tudo, convém observar que a questão da significação se coloca, para uma representação, em diferentes níveis de inteligibilidade.

Em termos do assunto sobre o qual se pense, considerado como unidade, a inteligibilidade corresponde à formação de uma imagem (ou representafão) do mundo, onde a representação específica se insere em uma visão geral ordenada em sua própria experiência, e a ele aparece, por isso mesmo, como um elemento inteligível desse mundo. Este último é considerado constituindo uma totalidade (relativa) dotada de sentido (os elementos estão integrados no todo). A constituição dessa imagem, ou representaçáo, reforça a possibilidade de dela abstrair a subjetividade ou o caráter contingente $\mathrm{e}$, por isso, a de conceber a realidade do mundo (que se coloca nesse nível de conjunto). $\hat{E}$ assim que se manifesta mais visivelmente o elo entre a própria inteligibilidade - relativa à forma $\mathrm{e}$ ao conteúdo das representaçóes - $\mathrm{e}$ a exigência de inteligibilidade, ou seja, o movimento do pensamento que impele a estabelecê-lo.

Qualquer conhecimento específico supóe uma inteligibilidade, que permite a intervenção de consideraçóes sobre a forma (particularmente, pela imposição de critérios relacionados à compreensão e à razão, que podem ser universais (5)) e sobre o conteúdo. Porém, por mais pontuais que sejam as inteligibilidades específicas, estáo todas relacionadas à inteligibilidade no sentido geral que tal assunto encontra $\mathrm{c}$ requer em seu pensamento do mundo. Em resumo, temos uma experiência localizada $\mathrm{e}$ parcial da inteligibilidade do mundo, porém, apenas a apreendemos como inteligibilidade porque a relacionamos com uma exigência global, que comporta noçóes como as de realidade e verdade.

Entretanto (e particularmente porque tais noçócs não são necessariamente evidentes e supóem uma variedade de acepçóes), a maneira de conceber a inteligibilidade náo é única: Um conhecimento que apenas se interessaria pela consideração dos dados empíricos tomados da forma como chegam, sem a preocupação de uni-los a uma racionalização mais 
ampla, certamente poderia ainda aspirar à inteligibilidade. É inteligível aquilo que está em concordância com a razão e nos é esclarecido pela compreensão, mas isto pode continuar sendo muito pragmático e parcial. Nossa proposta porém não é estudar aqui a questáo da inteligibilidade em toda sua generalidade. Como nos limitamos a considerá-la $\mathrm{cm}$ relaçāo às teorias que atingiram um estágio muito formalizado, admitiremos que, ao menos nessa área, a inteligibilidade se identifica, em grande parte, à racionalidade, concebida como ordenação dos elementos primitivos de conhecimento (a começar pelas sensaçōes) que nos são fornecidos. Einstein definia a inteligibilidade como a "possibilidade de ordenar a totalidade de nossas experiências dos sentidos "através da consideração de conceitos e de relaçóes de conceitos (6). Nessa direçáo, o ideal de simplicidade que ele atribuía à teoria física, e que corresponde a tal ordenação de um grau elevado, nada mais é que a mais alta expressão da inteligibilidade racional.

A própria existência da inteligibilidade, verificada por nossa experiência do conhecimento, não deixa, todavia, de apresentar o problema de sua possibilidade, que pode ser formulado nestes termos: como seria possível a inteligibilidade, ainda que haja um hiato lógico entre experiência e representação? Efetivamente, a relação entre as duas não vai das percepçóes (e dos dados empíricos) aos conceitos que elas engendrariam e que lhes seriam associados, mas, parte dos conceitos, simbólicos e construídos mentalmente, que nos permitem pôr ordem nas percepçōes e nos dados empíricos, de onde tiraríamos um conhecimento (assim, uma imagem do mundo). Com certeza, a origem do conhecimento reside na experiência (que se resume, em última análise, na experiência sensorial), mas, para ser esclarecida, ela necessita conceitos e outras livres criafóes do pensamento. A experiência assim esclarecida fornece o conteúdo físico das grandezas e das proposiçóes da física (inclusive seus princípios diretivos (7)). Portanto, o que justifica a representação nada mais é que o sucesso que ela obtém em sua relaçáo com a experiência; aliás, a relação apenas diz respeito à representação tomada na totalidade de sua estrutura, e não na soma separada de seus elementos, se rejeitarmos o critério verificacionista dos empiristas (em termos de relação direta entre os conceitos e proposiçóes, tomados separadamente, $e$ as possibilidades de experimentação).

Podemos apenas testemunhar esse sucesso sem justificá-lo. Einstein exprimia a essência desse estado de coisas da seguinte maneira: "A justificação dos constructos que representam a realidade para nós reside em sua capacidade mais ou menos perfeita em tornar inteligível o que é fornecido pelos sentidos" (8). Em outras palavras; a representaçáo está 
ordenada de acordo com a inteligibilidade (é estabelecendo nossa representação que compreendemos nossa experiência). Porém, nenhuma instância define a priori a inteligibilidade e, por conseguinte, a razáo do sucesso de nossa representação.

Apesar de seu aspecto pragmático, tal constatação năo chega a remeter, no final das contas, a definiçâo da inteligibilidade à experiência. Como vimos, a cxperiênucia só pode ser compreendida quando esclarecida (por conceitos, construçóes mentais). Além disso, a experiência propriamente dita sempre deve ser avaliada e criticada; para essa apreciação, nos apoiamos no guia da intuição e do sentido, físico que é a teoria de que dispomos, considerada em scu campo de validade (para ele, cśsa teoria é, até segunda ordem, para essc campo, o próprio substituto da experiência anterior, no exato sentido de que é ela a depositária do conteúdo físico). É útil evocar nesse momento o papel das experiencias de pensamento (9), concebidas como meio de investigar a coerência e a significação ou conteúdo físico dos conceitos e proposiçóes de um sistema teórico, relacionando-as por meio de uma experiência em princípio realizável, mas não realmente feita. Em particular, é possível esclarecer, por isso, o contcúdo físico de um conceito ou de uma grandeza, ligando-o ao de uma outra grandeza, intuitivamente melhor conhecida. Esse exemplo ajuda a ver como, transcendendo a contingência do resultado, o papel principal da experiência no processo de conhecimento é de conferir o sentido físico, ou seja, de fornecer a intuiģáo física, que é, para essa ciência, a própria substância da inteligibilidadc. Vemos como essa apreensão apcla para uma acepção muito particular da experiência, experiência racionalizada, que já supóe a inteligibilidade.

Quanto aos clementos racionais que intervêm em todo processo, na constituição da expcriência e em seu esclarecimento, são, eles mesmos, fruto de uma construção e năo se resumem nem à experiência imediata, nem a disposiçóes inatas do assunto. Por outro lado, face ao empirismo, uma concepção convencionalista estrita não é suficiente para estabelecer a intcligibilidade no sentido que escolhemos, que supóe, pelo menos até certo ponto, uma unicidade da representaçăo para um determinado campo. Em sua mais forte acepçáo, a inteligibilidade efetivamente corresponde à afirmaçáo de que existe um caminho próprio da teoria, e de que, segundo critérios racionais, é possível encontrá-lo.

A inteligibilidade está diretamente comprometida com a interpretação das proposiçóes e das grandezas teóricas, e assim estabelece as significaçōes e anuncia o conterido (físico, no caso aqui considerado). 'Eśsa interpretação faz parte do trabalho do físico, até a sua inserçáo em con- 
siderações mais globais sobre o conhecimento, tarefa própria da filosofia.

O conhecimento científico, tal como se mostra em diferentes áreas, obriga o afastamento de uma concepção tradicional da interpretação que o vê como o aporte (considerado necessário) de um acréscimo de sentido cxterior ao trabalho experimental e teórico propriamente dito. Cassirer, por exemplo, anteriormente evocava (10), a respeito da teoria da relatividade, a necessidade de uma "interpretação lógico-matemática" dos conceitos da teoria que transcende o "pragmatismo do físico", e que constituiria a própria tarefa do filósofo. Por sua vez, Bergson afirmava, ainda a respeito da relatividade, que a significação filosófica do conceito de tempo năo se satisfaz com o conteúdo que a teoria lhe fornece e que ela supõe um acréscimo de sentido, que não lhe pode vir nem do formalismo, nem da experiência, mas de um trabalho de discernimento conciliando os dois e fazendo-os participar do real e do convencional: o filósofo, a quem cabe esse trabalho, reestabeleceria assim a verdade da intuiçâo (11).

Entretanto, fazia-lhe observar Einstein, a significação filosófica do tempo passa pela sua significação física e, assim como ela, requer a crítica da simultaneidade que é ilusão da consciência: de maneira que o tempo do filósofo a esse respeito não é diferente do tempo do físico. Em outras palavras, a atividade crítica sobre os conceitos que Cassirer e Bergson, cada um por sua vez e, por razóes diferentes, reclamam, já pertence ao trabalho do próprio pensamento físico, que năo se permite reduzir a um simples arranjo do formal sobre o empírico, mas que constrói os conceitos munidos de sua significação: expressão de seu conteúdo, a significação (física) está implicada nos elementos originários da construção da teoria, como podemos ver pelo papel das definiçóes dos conceitos em termos de física e das hipóteses que lhes são subjacentes:

Evidentemente, essa constatação não poderia ser levada à concepção verificacionista das significaçóes tal como a concebe o positivismo ou o empirismo lógico (12), já que a coordenafáo dos conceitos e grandezas físicas à experiência só opera em consideração ao sistema teórico tomado em sua totalidade. A doutrina verificacionista, apesar de evitar, à primeira vista, o inconveniente de impor a significação do exterior, incorre, no final das contas, em semelhante erro, caracterizando, de modo arbitrário e redutivo, aquilo que um conteúdo de conceitos é.

Além da oposição formal e do empírico que caracteriza essas concepçóes, por mais diversas que sejam, a teoria (física, nesse caso) constitui a própria instância que outorga a inteligibilidade e, na qualidade de 
sistema de seus conceitos, comporta, de modo interno, por assim dizer, a necessidade de enunciar sua significaçáo física. Se a teoria é o conjunto de suas proposiçóes, é dela que deve vir, em primeira instância, o sentido das proposiçóes. Na verdade, isso diz respeito à própria natureza do objeto da teoria segundo a relação que descrevemos acima: essc objeto, que se supôs corresponder ao conteúdo da representação, é pensado como existente por si mesmo e as significaçóes que nele descobrimos, se corresponderem a tal conteúdo, estão relacionados a esse objeto e não a uma instância de decisão que lhe seria externa. Como tal, o objeto deve ser inteligível, apesar de ser do exterior que o esclarecemos.

Até certo ponto, essa consideração é de alcance geral: aplica-se a qualquer representação de qualquer objeto, que náo um simples modelo, e diz respeito tanto às ciências muito formalizadas quanto às menos formalizadas, ou então, às ciências exatas ou da natureza, quanto às ciências humanas ou sociais.

Um exemplo tomado emprestado às ciências humanas mostrará melhor que, nas ciências, trata-se o objeto como estando associado a uma teoria, seguramente interpretativa, mas não formalizada. Trata-se do dionisismo, fenômeno cultural e social da Grécia antiga por volta dos séculos VI e V a.C. Um homem do século $\mathrm{XX}$ o interpreta facilmente (como aliás, o carnaval, mais recente) em termos de válvula e de assimilação por parte da sociedade que o tolera ou que o admite para preservar sua estrutura. Porém, chamava-nos a atenção o historiador Jean Pierre Vernant. Quanto essa explicação lhe era proposta, Vernant a atribuiu ao homem contemporâneo (com seu modo racionalista de ver os fatos). Um comportamento deve ser apreendido como realidade, tal como $e$, sem interpretaçáo externa (13). A dimensão dionisiana faz parte do que é essa sociedade considerada em si mesma, e esta constataçăo é suficiente: todo o resto é tradução, reduçáo segundo os cânones que lhe são estranhos. De outra forma, a significação desses comportamentos dionisíacos não deve ser acrescida do exterior ao objeto (aí, a sociedade de entấo) onde eles se inserem. Sua significaçáo náo está apenas na tradução que fazemos segundo nossas normas, ela faz parte do objeto e é a partir do próprio objeto que deve ser expressa.

Em termos de teoria, se retornarmos ao problema de uma ciência formalizada, tal constatação a respeito do objeto da representação equivale dizer novamente que a significação se encontra no próprio conteúdo da teoria e, portanto, deve ser formulada (na medida mais possível) nos termós désta última.

Isto posto, existe uma importante diferença, em relaçáo à interpre- 
tação das proposições teóricas, entre as ciências exatas (da natureza) e as ciências humanas, na medida em que náo poderíamos falar, sobre estas, de teoria no mesmo sentido, e na medida em que o objeto é constituído de um discurso interpretativo (mesmo quando visamos a objetividade). $\mathrm{O}$ discurso interpretativo que corresponde às ciências exatas não é da mesma natureza trata-se pelo menos de um discursomínimo, codificado segundo símbolos com significados precisamente estabelecidos. A constituiçāo do objeto é a de conceitos ordenados e interpretados como vimos, e o termo discurso é inadequado para qualificar um sistema assim formalizado.

Podemos, entretanto, pensar que, apesar dessa diferença, tanto as ciências humanas como as ciências exatas se propóem a descrever um objeto descentrado em relação ao assunto epistêmico. Uma verdadeira revolufão copernicana da epistemologia consistiria precisamente nessa descentração de nossas representaçóes, pensada em todas suas implicaçóes. Freqüentemente opomos a um projeto dessa natureza o caráter construído de nossos conhecimentos, a impossibilidade constitutiva de abstrair-se da consideraçáo do assunto do conhecimento, da linguagem, do pensamento comum e da ação humana. Porém, podemos nos perguntar, considerando o que foi dito sobre o objeto, se não é primeiramente a ele que seria preciso relacionar a inteligibilidade, se a ordem e o sentido que nele descobrimos não correspondem fundamentalmente a um estado de coisas independente de nós, apesar de ser através de nosso esclarecimento que a nós ele se revela, e que sem o qual a nós permanece desconhecido. A percepçáo necessária das condiçôes do conhecimento em toda consideração do objeto deste, freqüientemente concebido como uma dissolução do próprio objeto nas circunstâncias de sua abordagem, não poderia, pelo contrário, permitir pensar o objeto separado dessa contingência (de certa forma, assim como na física, a crítica à arbitrariedade dos sistemas de coordenadas, aliás necessários, permite pensar as propriedades invariantes dos sistemas na teoria da relatividade)?

\section{Análise e interpretação das proposições teóricas}

A questão da interpretação das teorias, de seus formalismos e de seus enunciados obteve variadas respostas, tanto da parte dos filósofos das ciências, no que diz respeito ao problema geralmente considerado, como dos cientistas confrontados à interpretaçáo de uma teoria específica, como, por exemplo, em física, a mecânica quântica. Notaremos, todavia, que o problema da interpretação se coloca em diferentes níveis, e em diferentes momentos da imbricação dos elementos da estrutura teórica. É o que gostaríamos de precisar agora. 
Quando Schlick caracteriza, em seu livro Allgemeine Erkenntnislebre (14), os clementos da estrutura de uma teoria (representação simbólica de uma ciência da natureza) como sendo os axiomas, as proposiçôes derivadas e as definiçóes, aliás impossíveis de se distinguir umas das outras, cle inaugura uma concepção que justapóe o formalismo e o conteúdo, a sintaxe e a semântica, tanto para os elementos que entram na constituição do formalismo como para as proposiçóes que dele se inferem. Segundo essa concepção, a significação não faz parte da representação simbólica considerada em si mesma, e deve ser acrescentada à formulação de um enunciado: "os enunciados não interpretados são apenas regras gramaticais". É nesse sentido que a teoria é uma estrutura formal interpretada.

Nessa linha, o positivismo lógico e a filosofia analítica adotaram a tese da interpretaf̧ão parcial, segundo a qual a teoria consiste em um formalismo abstrato (F) e em um conjunto de regras de correspondência ou definif̧ões de coordenaģão $(\mathrm{R})$, que unem os termos presentes no primeiro aos fenômenos e dados de experiência. A questáo que se coloca é saber se esse conjunto por si só constitui uma teoria física ou se é preciso acrescentar-lhe outros elementos de interpretação de natureza diferente (por exemplo, para fazer dele uma teoria explicativa ou preditiva). Para a interpretacão segundo a metalinguagem que estabelece as regras de coordenação (por exemplo, associando a variável $\mathrm{X}$ a uma coordenada no espaço físico e à possibilidade de determiná-la pela observação), seria preciso, ou não, acrescentar elementos de interpretação mais gerais (de tipo metateórico ou até ontológicos ou metafísicos). Como no caso da mecânica quântica, a complementaridade ou, ao contrário, o realismo ou determinismo.

Se nos ativermos ao projeto ao qual nos propusemos, os elementos suplementares de interpretação deveriam ser evitados, pelo menos desde que continuemos na consideração apenas da ciência da natureza, isto é, neste trabalho, a física. Deixar intervir nesse nível a ontologia ou a metafísica é, com efeito, privar-se de tirar da física e da epistemologia tudo o que elas têm a dizer. Podemos, sem negá-las, porque pertencem às dimensóes do sujeito do conhecimento, julgar necessário retribuir seu recurso mínimo ao que é da interpretação da própria teoria, já que o objeto do conhecimento é concebido (e posto) como totalmente distinto do sujeito. Passado o estágio da definição e da escolha de um programa para o conhecimento, onde intervêm com grande evidência, essas disposiçóes filosóficas não deveriam intervir nas interpretaçóes específicas. Desejamos, de alguma forma, que a epistemologia encontre, nela mesma, o máximo de recursos próprios, e o problema, então, é o já men- 
cionado: encontrar, na reivindicação ontológica ou metafísica, um substituto epistemológico.

Para tanto, se excluirmos do exame da teoria física e de sua interpretaçāo as consideraçóes da filosofia geral, o problema da interpretaçáo se reduz à unica consideraçáo das regras de coordenaçáo entre os elementos do formalismo e os dos dados empíricos? De fato, o ponto de vista puramente estrutural que considera uma teoria física um formalismo interpretado apenas leva em consideraçáo um dos aspectos do que uma teoria física é. Esse ponto de vista identifica a teoria aos elementos (formais interpretados) que entram em sua constituição, sejam eles originais ou deduzidos; assim sendo, omite deles um aspecto assencial. A teoria não é reduzida a tais elementos, mas consiste em uma elaboraçáo sui generis (física, para sermos exatos) que os utiliza e os integra em um conjunto estrutural onde o formal $\mathbf{e}$ a interpretação estão estreitamente imbricados, segundo uma combinação que não se deixa dissociar nos elementos de partida. Nessa elaboraçáo, a dedução tem a sua participação, mas não apenas isso; de qualquer modo, está submetida às exigências requeridas pelos princípios físicos, referindo-se às relaçóes entre conceitos.

Em outros termos, a teoria física é construída por meio de um formalismo (matemático, por exemplo, a geometria para a teoria da relatividade geral) e de consideraçóes que condicionam a utilização desse formalismo (são consideraçóes físicas transcritas nele: por exemplo, a imposiçâo de um princípio de simetria ou de uma relaçăo de invariância). A teoria física não é, portanto, um formalismo interpretado (uma geometria interpretada, como no exemplo citado) (16). Sáo proposiçóes propriamente físicas que resultam dessa construção, para as quais se coloca, de agora em diante, a questão de sua interpretação, em termos que năo são os mesmos que os da interpretaçáo inicial (no sentido das regras de coordenação).

Consideremos o caso da mecânica quântica: desde que se constituiu como uma nova teoria, colocou o problema de sua interpretação, isto é, da interpretação de suas proposiçóes. Como lembrava Dirac sobre o assunto, "pela primeira vez em física, dispúnhamos de equaçóes antes de saber como interpretá-las" (17). Para interpretar fisicamente as grandezas tais como são fornecidas pelo formalismo (por exemplo, aquelas que unem as relaçóes de indeterminaçáo), sempre tivemos tendência para relacioná-las a sua antiga significaçăo, descrevendo-as como submetidas a um princípio de correspondência ou acrescentando às grandezas da antiga teoria uma condiçăo de utilização. Nesse caso, a interpretação 
relaciona-se, não sem inconveniente, à teoria precedente, e não à nova tcoria (particularmente, quando a nova teoria deixa intervir, por construçâo, grandezas que não têm semelhante analogia clássica e que o princípio de correspondência a seu respeito é mudo (18)).

O exemplo do princípio de correspondência é, aliás, bem indicado para mostrar como é possível uma outra concepção: ao invés de relacionar as grandezas a sua significação clássica, o que tem apenas um alcance limitado, já que isso só diz respeito aos pontos de concordância da nova à antiga teoria, é possível elaborar algumas grandezas da nova teoria a partir das antigas. Esse é o caso (ainda em mecânica quântica) da elaboração de operadores infinitesimais para representar as grandezas físicas. Mas; desde então, essas grandezas adquirem um novo sentido, irredutível ao antigo, já que sua própria forma matemática é diferente (trata-se de operadores, náo mais de números). A construção do tensor de momento-energia, em relatividade geral, a partir da métrica do espaço euclidiano infinitesimal tangente, é outro exemplo de processo semelhante. Uma vez construídas, essas grandezas não devem mais, com toda a certeza, sua significação física às antigas nas quais baseamos a construção. Uma vez que, precisamente, essa construçáo apelou para consideraçóes (abstratas, mas fundamentadas em uma necessidade física), que eram totalmente estranhas à antiga definiçáo das grandezas correspondentes.

Resulta que, em mecânica quântica, o problema da significação física das grandezas é abordado sob vários ângulos. Einstein caracterizava, em 1953, " a singularidade da situação atual ", nestes termos: " não é o formalismo matemático que pode ser posto em dúvida, mas a significação física de seus enunciados" (19). Em suma, o problema de saber o que dizem, fisicamente, as equações e, em particular, o que elas implicam, quanto ao conteúdo físico ligado à função (de onda) $\psi$. Nesse caso, para Einstein, o que diz a função $\psi$ sobre o estado individual de um sistema (20). Scrá preciso acrescentar à natureza um suplemento, que seria a interpretação? Qual seria a natureza dessa interpretação? A ambiguiidade prevalecente nesse ponto indica suficientemente a arbitrariedade de qualquer escolha considerada desta maneira: além do mais, podemos eliminar algumas dessas interpretaçóes, mas as razóes físicas de fazê-lo raramente são imunes da imposição de um princípio geral, físico ou filosófico, exterior às exigências estritas da teoria (por exemplo, a filosofia da complementaridade na obra de Bohr; ou o princípio físico de separabilidade local em Einstein, o qual, ele mesmo sublinhava, era estranho à mecânica quântica, mostrando sempre a sua incompatibilidade com a interpretação desta última em termos de representação de sistemas 
individuais; o que conclúáa à luz da interpretação da teoria conjuntivista da função $\Psi(21))$.

A interpretação probabilista da função $\Psi$ da mecânica quântica, indubitável quanto às suas consequiências, porém problemática quanto à sua natureza, permite ver exatamente como se imbricam o formalismo e o conteúdo físico na construção dos conceitos. A análise epistemológica de sua elaboração e sua formulaçáo mostrariam como o seu enunciado não precisa, de modo algum, recorrer a uma instância exterior de referência ou justificação. A interpretação de $\Psi$ como amplitude de probabilidade, de qualquer forma, resulta de suas propriedades no formalismo matemático escolhido para exprimir a teoria (o de vetores de estado definidos em um espaço de Hilbert); no entanto, esse mesmo formalismo era escolhido em função de sea adequaçăo para os problemas físicos considerados.

A interpretação física da função de onda (interpretação probabilista) exprime o que já pertence ao conceito (físico) matematizado, formalizado, e, assim, pertence à estrutura teórica. Porém, se o conteúdo físico do conceito matematizado já estivesse presente na estrutura teórica, restaria destacá-lo de forma explícita, isto é, enunciar a interpretaçáo. Aliás, foi o que fez Borh, sem recorrer a argumentos de natureza filosófica e atendo-se apenas ao trabalho teórico. Essa interpretafăo(física), que se impóe no próprio interior do trabalho teórico, ilustra o peso da formalização matemática característica da mecânica quântica.

Em seguida, coloca-se o problema do segundo estágio da interpretação, de fato, o de como interpretar a probabilidade que aqui está em questăo. A consideração precedente já indica que a probabilidade nẩo intervém como imposta de fora. O que nela vem de fora diz respeito à relafão de coordenafío com os dados de experiência que recaem sobre frequiências. Porém, na construção teórica, é através de uma grandeza física suigeneris que ela é pensada: uma amplitude de probabilidade o que é completamente diferente da importaçăo pura e simples do conceito de probabilidade. Como amplitude, sua forma linear implica a superposiçáo e acarreta a propriedade de interferência: trata-se de um conceito propriamente físico que difere da noçáo de probabilidade no sentido corrente e comporta mais, até mesmo se a ele se une, elevando ao quadrado seu módulo.

Essa concepção acarreta uma conseqüência quanto à interpretação da própria probabilidade. Se, de fato, é dessa maneira que a noģáo de probabilidade intervém na mecânica quântica, não há motivo para reto- 
mar a diversidade das possíveis interpretações das probabilidades geralmente consideradas - objetiva, subjetiva ou freqüentista (22) - uma vez que é no interior da própria teoria que a interpretaçăo física adequada será encontrada. De fato, a probabilidade exprimida pela funçáo $\Psi$ náo corresponde a um grau de ignorância, nem a uma freqüência de acontecimentos repetidos, mas a uma propriedade (objetiva) que se atribui a um sistema específico. A interferência de um único fóton (ou elétron ou nêutron) com ele mesmo, prevista pela teoria (resultante da superposiçáo das amplitudes de probabilidade) e devidamente observada, confirma-o. É apenas no nível da conexão com a experiência que a probabilidade se determina por medidas de frequiências: aí está o caráter da relação de coordenação que apenas une a grandeza teórica ao fenômeno, mas não $o$ identifica.

Esse estado de coisa está ligado ao problema da referência da teoria. O que representa a teoria quântica, considerada sob os aspectos de seu funcionalismo, em relação ao seu objeto? Os conceitos fundamentais da mecânica quântica, não obstante a sua representaçáo por símbolos abstratos (vetores de estado, operadores), correspondem a grandezas físicas exprimindo propriedades que se relacionam com o objeto da teoria. A esse respeito, nấo há diferença de natureza entre os conceitos quânticos e os conceitos clássicos, e nada obriga a priorizar a observação e a medida como referência privilegiada dos primeiros. Como para qualquer outra teoria física formalizada, a referência dos seus conceitos e proposiçóes encontra-se em seu objeto, isto é, nela mesma enquanto designa este último, sem nenhuma necessidade de traduzi-los em outro sistema conceitual que the seria estranho.

No exemplo que acabamos de citar, como em muitos outros, é a teoria, e nenhuma outra instância, que fornece a interpretaçáo física do conceito. Em consequiếncia, um conceito físico apenas adquire significação (pela atualização de todas as suas propriedades) de sua forma matemática no interior da teoria considerada. A interpretaçáo física dos enunciados, visando os conceitos, não pode ser acrescida do exterior, a menos que considere a teoria como irremediavelmente incompleta. $\mathrm{Na}$ verdade, feitas as reservas, certas situaçōes relativas à fase de elaboração teórica, em que os conceitos ainda năo foram precisados e em que devemos reinterpretar; como no caso das soluçóes com energia negativa da equação de Dirac (23). Notemos, entretanto, que essa reinterpretação se dá ainda no cerne da teoria, como a ela associada, tornando eventualmente mais vasta a rede de proposiçóes utilizadas, ora derivando proposiçóes já existentes (no caso, como o princípio da exclusão de Pauli), ora enunciando uma propriedade física suplementar; porém, esta 
nāo escapa à teoria como tal: assinala uma insuficiência, que precisará ser ultrapassada em uma teoria mais completa (neste caso particular, a teoria quântica dos campos).

\section{O objeto-alvo e o sistema}

O caráter sistêmico da teoria formalizada por uma ciência de conteúdo empírico (ou da natureza), como a física, é freqüentemente considerado como implicando a incomensurabilidade de teorias diferentes relativas a um mesmo campo de aplicação. Se o sistema ć autoconsistente a ponto de determinar o sentido dos conceitos e dos enunciados em função da disposição estrutural - esse sentido será necessariamente diferente para os conceitos e proposiçóes correspondentes, considerados no interior de uma estrutura diferente.

l'or outro lado, a ausência de inferência lógica entre os dados empíricos relativos aos fenômcnos de determinado campo e a teoria estruturada, que se propóe representar esses fenômenos, acarreta, em princípio, uma multiplicidade de possíveis sistemas teóricos equivalentes. Se estes são incomensuráveis, nấo há nada que permita escolher entre eles, senão por critérios puramente externos(24). $O$ valor de verdade das teorias estaria, assim, totalmente dissociado da significação de suas proposiçóes, e a questão da inteligibilidade estaria diante de um impasse.

Todavia, tais raciocínios se baseiam em uma concepção do caráter da teoria enquanto estrutura formal que não dá conta de algumas particularidades próprias a uma ciéncia da natureza, como o caráter da interpretação de que já tratamos. Quando falamos de teoria formal interpretada,em geral, entendemos uma estrutura puramente formal acrescida de regras de correspondência, interpretando cada elemento - rẹpresentado por símbolos - da estrutura, outorgando-lhes, assim, um conteúdo semântico. Porém, isto é conceber a interpretação como simplesmente justaposta à estrutura, quando, pelo contrário, ela é parte integrante do sistema. O sistema que a teoria constitui não é descrito de maneira satisfatória pelo modelo lingüístico da sintaxe e da semântica. $O$ seu caráter formal não a identifica em parte a uma estrutura puramente formal (por exemplo, uma teoria matemática) que seria sua parte sintática, apesar da axiomatização das teorias poder ser um procedimento fecundo em certas consideraçóes (para revelar as características de sua estrutura).

A própria forma da estrutura, dada pela ordenação de seus conceitos, é tributária da significação (isto é, do conteúdo) destes. Em contrapartida, pelo fato de a estrutura conter essa significação (expressa esse conteúdo), é dela que o enunciado deduzido pelo formalismo adquire 
significação e conteúdo físico. A riqueza da capacidade preditiva de uma teoria, como a mecânica quântica, considerada sob os aspectos de formalismo radical (25) fornece uma excelente ilustração do assunto. Se pudermos encontrar ou predizer, partindo dela (por exemplo, da propriedade de superposição linear da função de estado que descreve um sistema físico), propriedades físicas tão pouco comuns ou intuitivas quanto

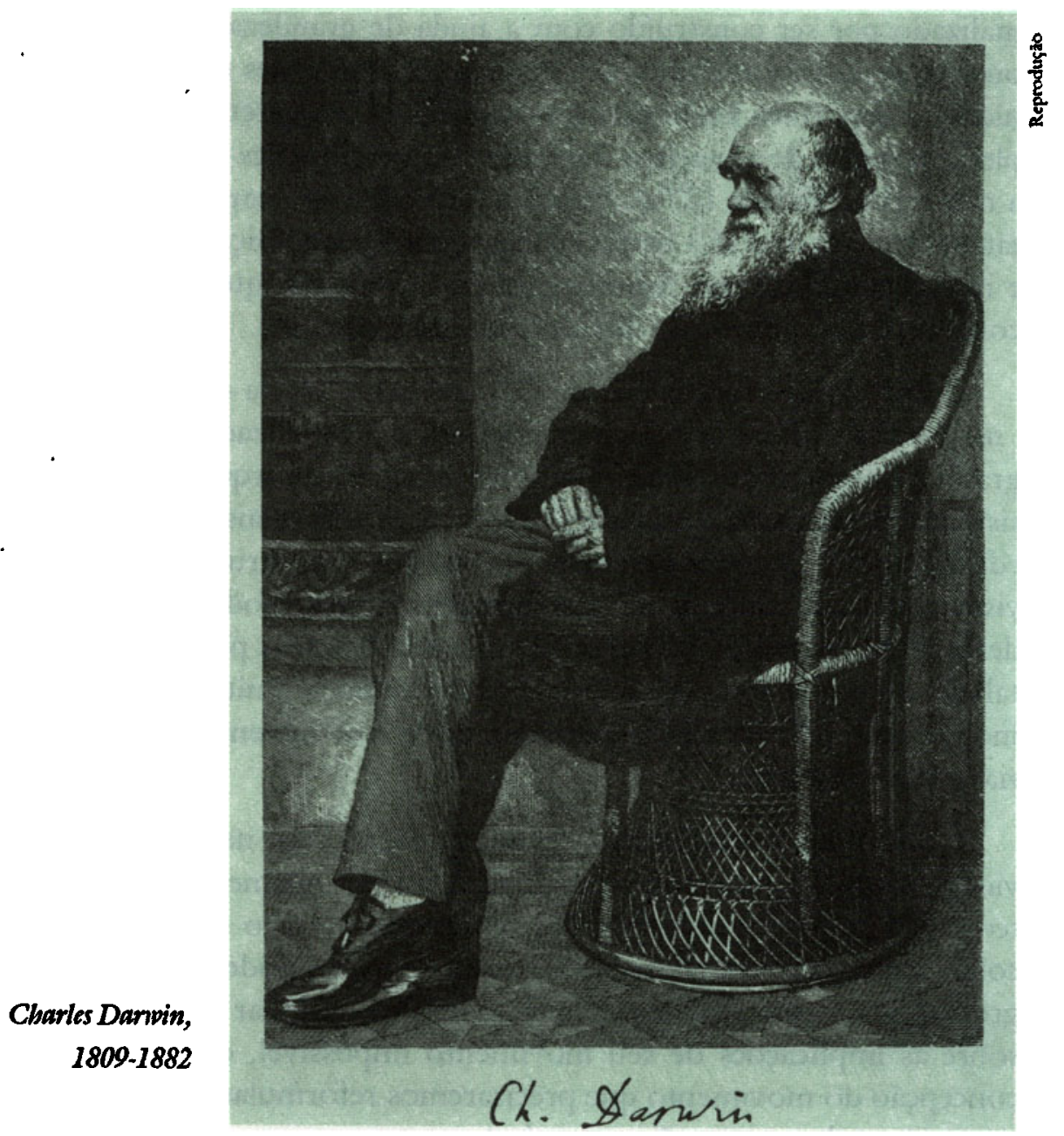

a interferência de uma partícula quântica com ela mesma, a indiscernibilidade ou a nâo-separabilidade local, que correspondem a fenômenos reconhecidos; é porque a propriedade formal contemplada conseguiu considerar um mesmo caráter fundamental dos sistemas quânticos à origem dessas propriedades. Tais propriedades físicas são manifestaçóes diferentes da natureza quânțica dos sistemas, da especificidade 
quduntica, se quisermos. O quantum de ação, a dualidade onda-partícula, as relaçōes de incerteza de Heisenberg são outras manifestaçóes da mesma propriedadc fundamental (26). A construçáo da teoria formalizada utilizou, para uma proposta deliberadamente física, grandezas matemáticas suscctíveis de dar conta de algumas dessas propriedades, munindo-as de uma interpretação física e submetendo-as a regras determinadas por consideraçōes físicas. Assim sendo, construíam-se conceitos ou grandezas físicas, constituídos em sistema, e esse sistema (físico, formalizado por ser construído com a ajuda de grandezas matematizadas, ou seja, cxpressas por símbolos que têm propriedades matemáticas definidas) comportnva em si mesmo capacidades interpretativas, por exemplo, a respeito de conceitos derivados ou proposiçōes deduzidas (como a não-separabilidade (27)). Pouco se vê como essa capacidade interpretativa seria possível se a teoria apenas fosse a justaposição de formalismo $e$ interpretação de que falamos (porém, é verdade que os que assim a concebem têm uma visão diferente de interpretação).

Em suma, em uma ciência da natureza, a teoria é uma construção sui generis elaborada a partir de conceitos formalizados (engendrados graças à interpretação de elementos formais). A sua arquitetura enquanto sistema não se reduz à estrutura dos elementos formais, assim como um edifício nâo se permite descrever apenas por sua estrutura. $O$ ponto de vista estrutural sobre as teorias formalizadas náo pode omitir a consideraçăo do conteúdo, isto é, da significação das suas proposiçóes. Aliás, talvez seja por tê-lo ignorado que nos apressamos muito em decidir pela incomensurabilidade e à impossibilidade de escolher entre diferentes teorias, como veremos.

Isto posto, notaremos que, nos fatos, ou seja, na realidade da atividade científica tal como se pode observar, a incomensurabilidade das teorias, a incomunicabilidade das representaçōes não são absolutas, escolhas entre elas são efetuadas e, a seu respeito, pode-se falar em progresso. Se a flecha de Zenon voar, antes de continuar nos perguntando sobre as implicaçóes de seu movimento impossível, é a nossa própria concepçáo do movimento que precisaremos reformular (para nós, o que pensamos sobre o que sấo as teorias).

Em primeiro lugar, a teoria, de fato, possui valores definitivos. Tais valores são, de um lado, os elementos de conceitos ou de princípios que servem diretamente para a construçáo de uma nova teoria a partir das antigas. Esse é o caso, por exemplo, do princípio da relatividade que se originou da mecânica clássica, da qual a teoria da relatividade restrita tem seu princípio fundamental de validade universal. Ou ainda, a constância da velocidade da luz, que provém da teoria eletromagnética, na 
qual se fundamenta a própria teoria da relatividade restrita para dar ao princípio (da relatividade) a universalidade (da mecânica ao cletromagnetismo, e a outras teorias físicas). $\mathrm{Ou}, \mathrm{o}$ quantum de ação e suas formulações equivalentes (28), que encontramos na teoria formalizada de que trata a mecânica quântica. Ou o princípio de exclusão de Pauli (inicialmente de natureza fenomenológica), que reconhecemos como sendo uma consequiência da estatística de Fermi-Dirac, isto é, da teoria das partículas quânticas indiscerníveis, etc.

De simples proposição deduzida, ou de fato formulado com base na observação, esses elementos podem passar ao status de princípio; ou de propriedade empiricamente constatada, ao status de proposição deduzida.

Exemplos como os anteriores demonstram como a nova teoria integra elementos - conceitos, fatos, princípios - da antiga teoria em uma construção de estrutura diferente, de tal maneira que, apesar de seu papel diferente nessas estruturas teóricas, sua formulação e seu conteúdo no sentido estrito são, nos dois, equivalentes, $\mathrm{e}$ a sua validade permanece universal. Certamente, se um fato considerado como tal em uma representação se torna elemento teórico ou princípio em outra, a significação da proposição correspondente difere de uma teoria para a outra quanto ao alcance dos respectivos conteúdos: como, por exemplo, a concep̧ão da relação dessa propriedade com outras, por eventualmente implicar outras na nova teoria (aliás, o que, sob esse aspecto, fornece um elemento de comparação das teorias pela fecundidade, o caráter unificador ou a simplicidade). Para tanto, a propriedade restabelecida em sua descrição elementar permanece a mesma, como os exemplos acima o mostram de forma mais clara.

O princípio de correspondência oferece outra maneira de avaliar os valores definitivos quando se passa de uma teoria a outra. Diz respeito, diferentemente das propriedades do gênero que acabamos de lembrar, à validade universal (ou transteórica), às propriedades ou relaçóes de grandezas válidas apenas na antiga teoria e encontradas na nova, como um limite, na aproximação de seu campo de validade (como as equações da mecânica de Newton, que correspondem ao limite, clássico da teoria da relatividade, etc.). Afirmamos que esse princípio não se justifica formalmente se considerarmos as duas estruturas teóricas, a significação de uma grandeza na nova teoria, não tendo correspondente na antiga, e que sua utilidade é unicamente prática, restabelecida, por exemplo, por consideraçóes numéricas. Todavia, se considerarmos que as estruturas teóricas não se reduzem à sua estrutura formal, $\mathrm{e}$ incluem de forma ajustada as interpretaçóes, o empecilho, no que concerne à consideraçáo do prin- 
cípio de correspondência para o problema da comensurabilidade, não tcm mais razão de ser. Pois o sistema interpretativo que requer conteúdos nảo tem a rigidez de uma estrutura puramente formal, axiomática e, nos fatos, conteúdos parciais podem ser colocados em correspondência.

$\hat{E}$ ainda nos fatos que constatamos o progresso das teorias e que, por isso, comparamo-nas e julgamos os seus méritos relativos. Sua incomensurabilidade alegada pela concepção puramente estrutural e formal, sendo contrária a essa evidência, está relacionada a razóes subjetivas ou ao consenso social. No entanto, as circunstâncias, responsáveis por esse progresso, as consideraçōes acerca das comparaçōes e das avaliaçōos dizem respeito às características dessas mesmas teorias, enquanto estas são sistemas interpretativos que carregam consigo conteúdos (29).

Um desses caracteres diz respeito ao aspecto cumulativo dos conhecimentos cịentíficos e das teorias correspondentes, que se apóia nos valores definitivos e nas correspondências parciais. Até mesmo por meio de representaçóes, é a soma acumulada dos conhecimentos precedentes, reconhecidos como válidos, que se acha integrada. O conhecimento (científico) nâo caminha para trás (salvo se se considerar as catástrofes que acometem as civilizaçôes), e, em última instância, a noção de passagem constitui exatamente parte integrante do método considerado, como condiçáo imposta para assegurar-se de que a nova representaçáo, no limite; reproduz a antiga (válida em seu campo), porque a contém e a ultrapassa.

Outras características das teorias se relacionam diretamente com a sua natureza dinâmica: uma teoria de conteúdo empírico não pode ser um sistema fechado. Está submetida aos julgamentos sobre sua verdade (relativa) e sua validade sempre se submete aos testes de confirmação: o que implica uma potencialidade permanente de modificaçăo. A necessidade de modificar uma teoria está relacionada ao conteúdo de suas proposiçóes e é em consideraçáo a esses conteúdos que o movimento das modificações se destaca. Âs vezes, é a própria forma (indissociável da significação) de uma proposiçáo fundamental que deixa aparecer as limitaçôes da teoria e pede o seu avanço. Einstein dizia a propósito da relatividade de forma eloqüente: " A teoria da relatividade restrita apontava para o seu próprio avanço", por sua restriçáo arbitrária da invariância dos únicos sistemas de inércia (30). Tal asserção evidentemente apenas tem sentido se compreendermos a teoria como um sistema que possui um conteúdo e apenas é justificado por ele.

O conteúdo físico, sugerido na estrutura formal, é causa de que a própria teoria é a fonte de sua dinâmica. Essa dimensão é obliterada se 
nos ligarmos apenas à interpretaçáo da teoria considerada como uma estrutura puramente formal; pelo contrário, é considerada quando se tem o ponto de vista da construção das teorias. Portanto, a construção é feita com vistas à adaptaçáo da teoria ao objeto-alvo e implica um caráter progressivo (tal caráter, que apela para uma idéia de continuidade, não é exclusivo de descontinuidades, uma vez que os desenvolvimentos podem chegar a reformulaçóes completas, essa dialética do contínuo e do descontínuo, reproduzindo, de qualquer forma, a dos conteúdos físicos e das estruturas formalizadas).

A adaptação da teoria ao objeto-alvo acompanha a evoluçáo das representaçốes que vai do senso comum às teorias físicas atuais, através de camadas sucessivas na espessura das sedimentaçóes e a densidade da história. Nesse campo sedimentar se preparou a forma atual da teoria e podemos encontrar aí o fio condutor da evoluçáo dos conceitos e das construções e modificaçṍes teóricas.

O fato da evoluçáo (histórica) das teorias constitui de qualquer forma o traço que apaga o ponto de vista exclusivo da estrutura, da distância entre o objeto-alvo e o objeto lógico da forma como o definimos acima. Caminho aberto para a exterioridade e para a história, o objeto-alvo da teoria parece à primeira vista distanciar-nos da consideração da teoria formalizada na qual propúnhamos ficar para estabelecer as significaçóes. Com ele, parece reintroduzir o próprio assunto, que havíamos excluído pelo método da teoria como sistema, já que o assunto define o objetivo, inclusive a escolha de seu programa (por exemplo, a representação de um mundo real, objetivo, isto é, podendo ser posto e apreendido como objcto independente do pensamento).

Resta-nos, então, ver como esse objeto-alvo - com o qual nos contentaremos, por rigor epistemológico, apenas em reconhecer o traço - nos permite conservar a referência das significações na teoria hoje formalizada, sem com isso perder o caráter aberto para o exterior de nossa representação.

\section{Um "sintético a priori "construído e funcional}

Voltemos alguns instantes para a natureza dos elementos racionais que, ao esclarecer a experiencia, constituem o conhecimento, e que condicionam a inteligibilidade: livres de conexão lógica com as experiências dos sentidos.(segundo a crítica de Hume sobre indução) e criação mental, estão próximos das convençóes no sentido de Poincaré. Porém, tais elementos comportam mais: por estar aliada a uma necessidade, se a teoria é fundamentada pela natureza de sua própria função é porque esses 
elementos são o fruto de uma elaboração no transcorrer da qual se impuscram.

Pelo primeiro aspecto constitutivo para o entendimento, possuem algo que os aproxima do a priori kantiano, que organiza o conhecimento da natureza. A física moderua, indicava Kant no prefácio da segunda edição da Crítica ì razão purara, nos ensinou que "a razāo apenas percebe o que ela mesma produz de acordo com os seus próprios planos", que cla deve colocar seus princípios para forçar a natureza a responder às suas questōes e "que ela deve procurar (...) na natureza, conforme as idéias que a própria razão para lá transporta, o que disso ela deve dela aprender e da qual cla nada poderia saber por si mesma" (31). Mas, se para Kant esses elementos racionais, conceitos, princípios ou categorias são a priori absolutamente independentes de qualquer experiência (32), aqui são apenas, conforme o seu segundo aspecto, dados porque foram postos e, mais precisamente, construídos de acordo com um conhecimento anterior, entāo, relativos c mutáveis.

Săo a priori no que têm de antecedentes e condicionam o pensamento do conteúdo da teoria e da experiência posterior: por exemplo, os princípios de uma ciência teórica (princípio da relatividade, princípios da Termodinâmica...). Isto quer dizer que, de fato, têm para o conhecimento uma função a priori. Quanto à sua natureza ou origem, são sintéticos, na medida $\mathrm{cm}$ que se apresentam como resumos de conhecimentos e experiências anteriores, estando a posteriori em relaçáo com estas. Sáo, pois, sintéticos por sua natureza e, a priori, por sua funçáo.

É a consideração do movimento do conhecimento e da evoluçăo dos sistemas teóricos, da reorganização em seu interior, dos conceitos e das proposiçóos que exige avançar a síntese a priori no sentido estrito de Kant e sua simples negaçấo, tal como a propóe o empirismo. Há uma oposiçẩo entre esses dois caracteres, sintético e a priori, e se considerarmos um conhecimento de natureza estática e a teoria como um sistema fechado, então, a natureza e a funçáo se identificam. Porém, se levarmos em conta o aspecto dinâmico do conhecimento e da teoria, uma coisa é a natureza e a origem, que fazem parte do conhecimento anterior, outra coisa é a funfüo, que se refere ao conhecimento atual (ou por se estabelecer). Em relação a esse conhecimento, ou seja, ao sistema da teoria considerada, o a priori funcional pode se dissociar da sua origem e do seu estatuto no conhecimento anterior. É apenas a priori no que concerne à sua limitada função nesse campo, e nấo o é apenas para o que é de seu modo de aquisiçăo.

Neste momento, vamos nos deter na presença, no esquema de 
conhecimento, de elementos (conceitos, proposiçóes) que têm a função de elementos racionais a priori e que, embora sejam provisórios na sua essência, manifestam um certo caráter de necessidade. São apenas a priori na medida em que são postos como condiçóes de possibilidade do pensamento físico e, particularmente, da teoria considerada, e não como impostos pela natureza do entendimento. Compreendemos que eles têm uma função a prioristica, mas nâo se trata de a priori absoluto.

O emprego, cm sentido relativo, da noção de a priori pode, na verdade, apresentar alguns inconvenientes e, antes de tudo, o risco de banalização, se apenas o entendermos como o que vem antes, como a hipótese em relação à experiência segundo Claude Bernard (33). Todavia, é interessante vê-la invocada em um sentido que acentua a sua função de inteligibilidade, sublinhando sempre o caráter construído e evolutivo desse elemento racional, por pensadores tão importantes como Poincaré e Enriques e, para este, Helmholtz, Brunschvicg e Cassirer. Lembrando as associaçóes de idéias que resultam do acúmulo de experiências anteriores, Poincaré se perguntava se náo são elas que "constituem essa forma a priori da qual nos dizem que temos a intuição pura", e, se fosse esse o caso, declarava não ver " por que a teriam declarado avessa à análise e (por que) tcriam (...) renegado o direito de pesquisar a sua origem" (34). Quanto a Enriques, sua concepçâo do a priori (condiçáo de possibilidade da ciência) não é a "de uma hipótese geral sobre o fundamento das coisas conhecidas, mas (de) um aporte da atividade do intelecto que interpreta a experiência e constrói a ciência". A definição desse a priori é "um progresso realizado em função da experiência", na qual ele via exemplos nas geometrias não-euclidianas e na teoria da relatividade (35).

Essa interpretação de um a priori relativo e construído se opóe à concepção kantiana no sentido estrito. Porém, isso não invalida a terminologia, se contribuir para sublinhar uma função fundamental de intcligibilidade. Os positivistas e empiristas lógicos recusavam toda acepção do a prioridesse gênero, que Schlick chamava "a priorimaterial" ou "factual" e que remetia ao idealismo subjetívista e à metafísica. $\mathrm{O} a$ priori, para ele, podia ser apenas formal, no que concerne a proposiçóes analíticas ou lingiuísticas, e assim, tautológicas (36).

Entretanto, se a "tese fundamental do empirismo moderno" tal como a estabelece o Manifesto do Círculo de Viena é "a recusa da possibilidade de um conhecimento sintético a priori" (37), é bastante natural para uma filosofia racionalista reexaminar os considerandos do proibido e se perguntar, com toda razão, se a idéia rejeitada na acepção estrita náo comportaria, apesar de tudo, uma dimensão cuja consideração 
seria essencial. O "transcendental" pode ser definido de forma menos restritiva que em sentido kantiano, por exemplo, como "qualquer condiçāo formal do conhecimento que determina a priori um tipo de objetividade " ("formal", evitando a remissão direta à observação e a priori sublinhando o caráter constitutivo), como o propóe Granger. Năo se trata mais de uma estruturação invariável de experiência (remetendo à norma de uma subjetividade), mas sim, mutável. E assim, o a priori diferentemente do sentido de Kant - liga-se em parte à idéia de trabalho do pensamento, que opera sobre as formas e os conteúdos, transformando-os. É esqueleto de um projeto e regras do jogo (38).

É, pois, em acepção semelhante que o entendemos aqui, considerando que a função do sintético a priori é de determinar os critérios de inteligibilidade. Por isso, vamos chamá-lo de sintético a priori funcional.

Os elementos fundamentais de uma teoria, uma vez constituída, nos quais outros estão baseados, constituem elementos racionais a priori deste gênero: ć para cles que resumem de qualquer forma o conteúdo da teoria, que é relatado o sentido dos enunciados derivados. $O$ que fundamenta a sua legitimidade, servindo de referência, é o efeito de arrebatamento na resolução dos problemas, ora inicialmente colocados, ora inéditos, descobrindo teoricamente, isto $\dot{\epsilon}$, antecipando novas características dos fenômenos. Esse efeito de arrebatamento que se destaca pela preditividade destaca-se também pela construçáo suscitada de novos conceitos e pela decantação de dificuldades epistemológicas iniciais operada em favor da familiaridade e da aplicação prática da teoria.

A mecânica quântica fornece, por exemplo, ilustraçóes imediatas: ver como seu formalismo é empregado para resolver problemas sem mais referências às situações clássicas e como ultrapassou um formalismo julgado em determinado momento como equivalente (o da mecânica ondulatória), exatamente por ser mais arrebatador, fundamenta de forma mais completa os conceitos (isso, sem interessar-se em saber se tal fundamento ainda bastasse). Tal efeito de arrebatamento da teoria considerada em si mesma (e por isso, até certo ponto, seríamos tentados a falar de autofiundamento) se destaca ainda em acréscimo de compreensão ocasionada pela única consideração do formalismo (mas sabemos que este não se dissocia da interpretação. Ver a propriedade de não-separabilidade local, já presente no formalismo, mas da qual foi necessário assegurar-se de que realmente correspondia a um fato, isto $\dot{\epsilon}$, a uma característica dos fenômenos físicos, e que difere de maneira radical daquilo que o nosso pensamento intuitivo estava habituado (39). A fórmula de Langevin resume muito bem estados de coisas dessa natureza: 
"O formalismo de nossas teorias conhece mais física do que nós, e nele podemos confiar" (40). Apesar de possíveis interpretaçóes, é desta maneira que podemos compreender o comentário de Hertz: "As equaçóes de maxwell são a teoria de Maxwell" . Em outros termos, as propriedades e as significaçōes são dadas pela teoria formalizada e apenas por ela (cujas equaçốes fundamentais resumem os princípios, os conceitos $e$ as relaçóes de conceitos).

Se a teoria, por assim dizer, se permite com toda legitimidade, tanta segurança, sem dúvida, é por comportar algo como a expressão de uma necessidade, qualquer que seja, própria ao objeto que ela tem como papel descrever. Sua própria forma teórica leva consigo esse efeito, que não pode ser transportado para outra instância (a menos que se mude de teoria). De outra maneira, seria dizer que a teoria constitui sua própria referência por designar um objeto pensado em sua necessidade, em sua exterioridade, e por ser assim mais do que simplesmente convencional.

A necessidade que distingue (ou trai) o arrebatamento da teoria implica que esta mantém em relação ao objeto que ela visa uma relaçăo que, além da simples convençáo, possui um alcance estrutural: a teoria e o seu objeto nã́o são exteriores um ao outro, sustentam-se e constituemse mutuamente. Qualquer modificação da teoria é modificação do objeto. Todavia, é necessário dizer que elas não se confundem, pois a teoria não é a teoria de si mesma, o objeto é o objeto de alguma coisa (de uma descrição), e o estatuto epistemológico deles é distinto (41).

A referência de uma representação teórica não está em uma instância preexistente (nem as características da intuiçáo ou do entendimento do sujeito transcendental, nem a linguagem, nem a experiência). Em particular, isso aparece nitidamente quando se trata do problema da novidade em ciência, ou seja, do que assegura o seu aspecto de novidade (de que apenas a nova teoria, que o integra, pode realmente expor) (42). Assim, é necessário tomar como referência a própria teoria constituída, que contém o sintético a priori específica de que precisa a inteligibilidade. O objeto que a teoria almeja, designa e representa, julga-se constituir ao mesmo tempo sua instância de referência. Daí essa exigência, para uma teoria formalizada, que a teoria deva ser suficiente para tratar por si mesma de seu objeto, e essa proposiçáo que está na teoria, que se superpóe ao seu objeto, encontrem aí os seus elementos de significação. Se falarmos de interpretação, pode ser apenas no sentido da explicitação crítica de seus problemas ou conceitos, do conteúdo ou sentido físico deles (por exemplo, em mecânica quântica, a inseparabilidade, a concepçáo física das probabilidades, a teoria da medida (43)), tais como se 
apresentam de acordo com seu sistema, e não o de um acréscimo de conteúdo ou significaçáo. Chamaremos essa propriedade de endo-referência.

Assim, a teoria encontra no objeto, que ela mesma designa, a sua referência para a significação de suas proposiçóes: porém, essa referência em si mesma não pode ser tomada em sentido absoluto, pois a teoria se confundiria, então, com uma axiomática(44) (é por isso que dizemos endo e nāo auto-referencial). O sistema da teoria (física) e do seu objeto (físico) não pode ser fechado: o objeto pode (deve poder) evoluir e modificar-sc. A situação é apenas metaestável: a referência em si mesma é apenas efetiva na medida em que o objeto que acaba de ser caracterizado pode ser considerado (provisoriamente) como um dado estável, no qual a teoria pode se basear como se the fosse exterior $e$ anterior, e assim, interpretar-se a experiência.

As proposiçóes fundamentais, que designam esse objeto (e se confundem provisoriamente com ele), têm a esse respeito - para nosso entendimento e para o nosso pensamento teórico - a funçăo de um sintético a priori, conforme o que vimos acima. O sintético a priori, entendido nesse sentido, é de qualquer forma um centro instantdneo de referencia, uma vez que a diferença entre o objeto-alvo e o objeto designado (objeto lógico da teoria), que determina entre eles uma distância, apela para um movimento: a teoria é uma estrutura dinâmica e não estática.

Todavia, do sintético a priori, essa proposiçāo-objeto tem apenas a funçáo. Foi apenas posto como tal (nos fatos, na prática do trabalho do pesquisador e de sua concepçáo da teoria, geralmente sem a terminologia!) por uma decisão para a qual tem muitos motivos, mas que não é imposta por penosas obrigaçóes, do tipo da lógica ou da natureza do pensamento. É um sintético a priori relativo, construído, que foi precedido por outras formas, e que tem uma origem. Porém, o que importa, quaisquer que sejam a sua natureza e origem, é que essa proposiçăo-objeto sintética tenha, no momento em que nós a consideramos, essa função constitutiva de inteligibilidade tal como a filosofia crítica de Kant soube muito bem expressar.

O sintético a priori funcional acumula, em um estado de dada teoria, a distância entre o objeto lógicoda teoria e seu objeto-alvo, ocupando provisoriamente, por assim dizer, um lugar vazio, mas que é necessário ocupar se quisermos que o pensamento teórico funcione: o lugar do objeto-alvo, que náo sabemos designar de outra maneira. Porém, esse lugar não é outro senáo o mesmo do "real pensado programaticamente" de que fala Einstein (45), ou seja, o lugar-inocupado porque é inocupdpel, 
no espaço do pensamento simbólico, da realidade física que nos propomos a representar, exterior a este espaço. $\mathrm{Na}$ realidade assim posta e, do outro lado, no assunto que dela se exige, estão escondidas a ontologia e a metafísica que não deixam de achar-se à parte do projeto de conhecimento.

A questâo da referência continua, em última instância, submetida a essa realidade fora de alcance, mas cujo arrebatamento do objeto e o correlativo da teoria (ou o inverso, uma vez que é freqüentemente a teoria em sua própria forma que o implica) levam consigo a marca. Entretanto, ela é passível de uma solução operatória, sem sair da consideração da física, já que dispomos de um substituto epistemológico do real (tal como está posto), que é o sintetico a priori (46) funcional e construído.

\section{Notas}

1 Einstein 1921.

2 Carnap 1966.

3 Por exemplo, as constantes de interaçáo ou as massas e cargas das partículas.

4 Solvre a quicstion da simplicidade e das diversas concep̧̧óes a seu respeito, de Poincaré a Einstein e a Reichenbach, ver Paty (no prelo).

5 Por exemplo, "O critério puramente lógico da verdade, a saber a concordáncia de um conhecimento com as leis universais e formais do entendimento e da razäo, é assim a condiçāo sine quan non e, por conseguinte, a condiçán negativa de qualquer verdade" (Kant 1781, 2a ed., 1787, $2^{a}$ parte, Lógica transcendental, III).

6 CC., por exemplo, Einstein 1949.

7 Por exemplo, os princlpios da mecanica ou da termodinámica ou da teoria da relatividade, etc.

8 Einstein 1949. Cr. Paty (no prelo), cap. 11.

9 Experilncins mentuis, Gedankenexperimenten, Thought experiments...

10 Cassirer 1921. Ver Paty (no prelo), caps. 1 e 12.

11 Bergson 1922, e sua intervençäo como a resposta de Einstein em Einstein et al.1923, Paty (no prelo), cap. 12.

12 Cr., por exemulo, Reinchenbach 1949, 1951, 1978.

13 Jean-Pierre Vernant, "Razäo e loucura entre os gregos antigos" , Conferéucia da Uniāo Racionalista, Collège de France, 23/1/1987, e em resposta a uma pergunta de Yves Galifret. No momento, anớtei a observaçăo de J.-P. Vernant, assistindo a essa conferéncia, 
surpreso por sua profundeza e por seu caráter de generalidade no que concerne à objetividade em história e, além da história, a significaçăo intrf́nseca dos acontecimentos.

14 Schlick 1918.

15 Carnap, Hempel, Nagel, Suppes, Sneed, Stegmüller, etc.

16 Paty 1989.

17 Dirac 1977.

18 Por exemplo, certos números quânticos que têm uma funçăo em teoria quântica dos campos (isospin, sabores, cor...).

19 Einstein 1953 a. .

20 Paty (no prelo), caps. 7 ao 10.

21 Por exemplo, Einstein 1949, 1953 a e b. Ver Paty (no prelo), cap. 10.

22 Cf. Bunge 1981, 1987; Paty 1990 a.

23 A reinterpretação proposta por Dirac dos estados de energia negativa, solução de sua equaçāo do elétron relativista, faz intervir a noçāo de antiparticula. Como nāo existe particula de energia negativa, Dirac postula que todos os estados de energia negativa estão ocupados (o que faz intervir o prinć́pio de exclusão de Pauli, segundo o qual dois elétrons idênticos nắo ocupam o mesmo estado) $\mathrm{e}$, tais estados, tomados em um oceano compacto, não podem entāo se manifestar. Um aporte de energia pode deixar passar de um desses estados a um estado de energia positiva (elétron físico normal). $O$ burreo no conjunto compacto dos estados de energia negativa é interpretado por Dirac como uma antiparticula de energia positiva (pósiton): o par elétron-buraco corresponde à criação de um par particula-antipartícula. A teoria quântica dos campos evita, por seus conceitos e formalisıno, sempre se baseando na equaçáo de onda relativista (de Dirac, para os elétrons), a ficção de estados de energia negativa.

24 Concepçóes como as de Hanson, Quine, Kuhn, Feyerabend, apesar da diversidade deles, estão na crítica que fazem da racionalidade em nome da incomensurabilidade. $\mathrm{O}$ argumento principal dos partidários da incomensurabilidade reside na "presunção do que uma escolha racional entre teorias apenas é possivel se essas teorias puderem ser traduzidas em linguagens recíprocas ou em uma terceira linguagem, que seria teoricamente neutra" , observa Laudan que a elas opóe a idéia de " problem solving", ou seja, que essas teorias se propōem resolver um mesmo problema (Laudan 1977, p. 142); por isso, essas teorias têm uma medida comum e existe um termo de comparaçáo entre elas. A perspectiva que propomos aqui se encontra, nesse aspecto, coin a de Laudan pela atençāo dispensada aos conteúdos. Devemos mencionar também a concepção " semântica não-formal" das estruturas teóricas propostas por Stegmüller (Stegmüller 1973, 1979), na linha da axiomatizaçăo (formal e do grupo de Bourbaki) de Suppes e (informal) de Sneed, para as teorias físicas. Ela considera, pela anexação de nofócs pragmíticas como a da evolução teórica, a efetividade do processo de conhecimento cientffico, conservando sempre a racionalidade da ciência. Ver, especialmente, as suas observaçóes sobre a incomensurabilidade (Stegmüller 1979, cap. 11). A posição de Dilworth (Dilworth 1981, 1989), a partir da sua crítica ao modelo dedutivo comum à maioria dos filósofos das ciências desde o empirismo, estando de acordo com a teoria física um estaturo especifico (que a distingue do enunciado de leis e valoriza os modelos que ela comporta) e recusando o 
aspecto puramente estrutural da teoria, concorda mais com a que é aqui apresentada. Todavia, exatancnte onde cle insiste nos modclos, contentamo-nos em sublinhar o caráter construído, presente na questão das significaçōes e fundamentamo-nos no aspecto não-estático e histórico.

25 Em termos de verores de estado de um espaço de Hilbert e de operadores agindo sobre esses cstados, ctc.

26 Demos um exemplo da solidariedade de todas essas propriedades dos sistemas quânticos: foi apenas estabclecendo a indiscernibilidade das partículas idênticas, $\mathrm{cm} 1925$ 1926, que se deu conta da profunda razão física da necessidade de introduzir o qunntum de ação como o fez, Planck em 1900, no qual todos acreditaram (CC., por exemplo, Paty 1988 a, cap. 6).

27 Ver Paty 1986.

28 Citados anteriormente, os valores teóricos que aqui consideramos estão ligados a fatos e leis de natureza experimental. Porém, é sob a formulação teórica que llhes corresponde que devemos encará-los, umn vez que é a comparação das teorias que nos interessa. Dilworth (op. cit.) os considera, por sua vez, enquanto se trata de leis empíricas, na medida em que insiste na distinção entre as leis (empíricas) e as teorias (como abstraçōes). Essa distinção nos parece problemática, já que a formulação das leis - até mesmo o enunciado de fatos - já comporta uma teorizaçăo.

29 Certamente, as circunstâncias da recepção das teorias são tributárias de outras perdas. Mas é claro que, no final das contas, a escolha de teorias, em física por exemplo, não é relegada à arbirraricdadc social...

30 Einstein 1919.

31 Kant 1787.

32 In Kant 1781, ed. 1787, Introduçẩo, I.

33 "A idéia a priori, ou mellıor, a hipótese, é o estímulo da experiência", escreve Claude Bernard em Introduction ì l'tude de la médecine cxptrimcntalc (citado por Paul Fouquié em Dictionnnirc de la langue plsilosoplsique, como definição do a priori relativo por oposição ao a priori absoluto kantiano).

34 Poincaré 1903 , p. 96.

35 Enriques 1941. Segundo ele, essa concep̧̧ão era também a de Helmholtz, Brunsclıvicg e Cassirer.

36 Schlick 1930.

37 Hahn, Neurath, Carnap, 1929.

38 Granger 1968, ed. 1988, pp. 11-2.

39 Pary 1986.

40 Langevin 1964. 
41 Esse estado de coisas está ligado à noção de completude teórica nos dois sentidos dos termos, que são, de um lado, a adequação da teoria ao seu objeto (sentido lógico) e, de outro, a capacidade da teoria em formalizar totalmente um objeto unificado (sentido de conclussito). Ver Paty 1988 c e 1990 b.

42 Ver Paty 1988 b.

43 Apesar de tudo, pode ser que essa interpretação năo seja obtida: por exemplo, que o problema da medida permaneça sem soluçăo em mecânica quântica. A teoria, quanto mais formalizada ela for, permanece entāo incompletr.

44 Evidentemente, feita a reserva de que, mesmo sob a forma axiomática, ela não poderia ser suficiente para basear-se em si mesma (teorema de Gödel).

45 Einstein 1949.

46 De certa forma, no sentido que aqui consideramos, o sintttico remete a esse caráter do real de ser dado, o a priori ao que é posto (isso por meio de outros esclarecimentos precedentes).

\section{Bibliografia}

BERGSON, Henri 1922. Durte at simultenutitt: it propos de la thtorie d Einstein, Alcan, Paris, 1922.

BUNGE, Mario 1981. Four concepts of probability. Applied Mathematical Modelling 5, 1981, pp. 306. 312.

BUNGE, Mario 1985. Trentise on basic philosophy, v. 7: Epistemology and methodtology, In: Philosophy of science and technology. Part I: Formal and pbysical sciences. Reidel, Dordrecht, 1985.

CARNAP, Rudolf 1966. Plsilosophical foudations of physics. Basic Books, New York, 1966 (Trad. fr. de J.-J. Luccioni e A. Soulez. Les fordements philosophiques de la physique, Armand Colin, Paris, 1973).

CASSIRER, Ernst 1921. Zur Eiustein 'schen Relativitittstheory, Bruno Cassirer, Berlin, 1921 (Trad. ing. Einstein s theory of relativity considered from the epistemological standpoint, in Cassirer 1923, ed. 1953, Pp. 347-360).

CASSIRER, Ernst 1923. Substance and function and Einstein's theory of relatipity (Trad. ing. de William Curtis Swabey and M. Collins Swabey. Open Court. Chicago, 1923 : Dover, New York, 1953).

DILWORTH, Craig 1981. Scicntific progress, Reidel, Dordrecht. 1981: ed. aum., 1986.

DILWORTH, Craig 1989. On the nature of scientific laws and theories. Zeitserift fiir allgomeine Wisstuschnfttscoric. Stuttgart XX. 1989: $\mathrm{n}$ 1, 1-17.

DIRAC, Paul Adrian Maurice 1977. The relativistic electron wave equation. Proceedingr of the 1977 European Conference on particle physics. Budapest, 1977, v. I, pp. 15-34.

EINSTEIN, Nbert 1919. My theory. The Times. London, November 28, 1919. 13: retomado sob o título "What is the theory of relativity?" in Einstein 1954 c, pp. 222-7 (Original alemão: "Was ist Relativitätstheorie?", in Einstein 1934, pp. 127-31).

EINSTEIN, Albert 1921. Geometrie und Erfahrung. Preussische Akademie der Wissenschaften, Sitzungsberichtc. 1921, parte 1, 123-1307 (Trad. fr. de M. Solovine, La géométric et l'expérience, in Einstein A., Réflexions sur l'electrodynamigue, l'cther, In gtombtrie ot la relativitt, nova ed., Gauthier-Villars, Paris, 1972, pp. 75-91).

EINSTEIN, Albert ct al. 1923. La théorie de la relativité (Seçāo de 6 de abril de 1922). Bulletin de la Socitt franfaise de philosophicXXVII, 1923, 91-113: retomado em La Penste, no 210, fev. 1980, 12-29 (Trad. ing. Theory of relativity, Nature CXII, 1922, 253).

EINSTEIN, Albert 1934. Mein Wcltbilh,Querido, Amsterdam,1934. 
EINSTEIN, Albert 1949. Reply to criticism. Remarks concernig the essays brought together in this cooperative volume, in Schilpp 1949, Pp. 663-93.

EINSTEIN, Alhert 1953 a. Elementäre Ueberlegungen zur Interpretation der Grundlagen der Quanten-Mechanik, in Scientific papers presented to Mnx Born on his retirement from the Tait chai of natural philosoplyy in the University of Edinburgh, Oliver and Boyd, Edinburgh/Hafner, New York, 1953, pp. 33-40 (Trad. fr. Réflexions élémentaires concernant l'interpretation des fondements de la mécanique quantique, in Einstein,1989, pp. 251-6).

EINSTEIN, Albert 1953 b. Einleitende Bemerkungen über Grundbegriffe. Remarques préliminaires sur les principes fondamentaux (Trad. fr. M.-A. Tonnelat), in Louis de Broglie, plysicien et penseur, Albin Michel, Paris, pp. 4-15.

EINSTEIN, Albert 1954. Ifcas and Opitions, trad. ing. S. Bergmann, Crown, New York 1954. Reed. Laurel, New York, 1981.

EINSTEIN, Albert 1989. Ocubres choisies, v. 1: Mecanique statistique et phyrique quantique. Textos escolhidos e apresentados por F. Balibar, O. Darrigol e B. Jech. Traduzido do alemão. Seuil, Paris, 1989.

ENRIQUES, Federigo 1941. Causalité et déterminisme dans la philosophie et l'histoire des sciences, Hermann, Paris, 1941.

GRANGER, Gilles Gaston 1968. Essai d'ume plilosophie du style, Armand Colin, Paris, 1968; ed. rev., Odile Jacob, Paris, 1988.

HAHN, Hans; NEURATH, Otto; CARNAP, Rudolf 1929. Wissenschaftlische Weltatelassung der Wiencr Kreis, Wien, 1929. Reproduzido in Neurath 1979, pp. 81-101.

HANSON, Norwood Russell 1958. Pattorns of disconery. An inquiry into the conceptual foudations of science, Cambridge University Press, Cambridge, 1958; reed., 1972.

KANT, Immanuel 1781. Kaitik der reinet Vernunft.J. F. Hartknoch, Riga, 1781, $2^{2} \mathrm{ed}$., ibidem, 1787.

KANT, Immanuel 1787. Prefácio da 2 ed. da Critique de ln raison pure (Trad. fr. in Kant 1980, pp. 734-55).

KANT, Immanuel 1980. Ocumres pbilosoplsiques, v. I (Trad. fr. ediçâo publicada sob a direção de Ferdinand Alquié, Bibliothèque de la Pléiade, Gallimard, 1980).

LANGEVIN, Paul 1964. Ln petuste et $l$ 'action, edição preparada por Paul Labérenne, Ed. Sociales, Paris, 1964.

LAUDAN, Larry 1977. Promress and its problans: tomards a theory of scientific growth, University of California Press, Berkeley, 1977.

NEURATH, Otto 1979. Wissenchschaftliche Weltauflasung. Sozialimms und logische Empirimnus, editado por Rainer Hegselmann, Suhrkamp, Frankfurt, 1979.

PATY, Michel 1986. La non-séparabilité locale et l'objet de la théorie physique. Fundamenta Scientiae, 7, 1986, pp. 47-87.

PATY, Michel 1988 a. Ln matière dtrobte. L'appropriation critigue de l'objet de la physigue contemporaine, Archives contemporaines, Paris, 1988.

PATY, Michel 1988 b. Science et philosophie: la nouveauté et sa référence, in A. Robinet (dir.), Doctrines et concepts, 1937-87. RǴtrospectire et propspective: cinguante ans de philosophie de langue frangatise, Vrin, Paris, 1988, pp. 335-46. Igualmente in Paty 1990 c, pp. 15-27.

PATY, Michel 1988 c. Sur la notion de complétude d'une théorie playsique, in Fleury, N.; Joffily, S.; Martins Simóes, J. A. and Troper, A. (eds.), Leite Lopes Feschrift. A pioneer plysicist in the thivd world, World scientific publishers, Singapore, 1988, pp. 143-64.

PATY, Michel 1989. Interprétation et construction dans le rapport des mathématiques à la physique. Fundamenta Scicutiae 10. 1989, pp. 35-55.

PATY, Michel 1990 a. Probability and reality in Mario Bunge's Treatise, in Georg Dorn and Paul Weingartner (eds.) Studies on Bunge 's Trentise, Rodopi, Amsterdam-Atlanta, 1990, pp. 301-22.

PATY, Michel 1990 b. Remarques épistémologiques sur l'objet commun de la physique des particules et de la cosmologie, in Audoze, Jean: Musset, Paul e Paty, Michel (dir.), Les particules et l immirers, Presses Universitaires de France, Paris, 1990, Pp. 47-75. 
РАГY, Michel 1990 c. L hunlwse critigue Nes scicnces on le tetraddre épisttmologique, L'Harmattan, Paris, 1990.

PATY, Michel (no prelo). Einstcin plsilosoplse. La plysique comme protigue philosophigue (relatipt, quanta, episttmologic). Presses Universitaires de France, París.

POINCARÉ, Henri 1903. L'espace et ses trois dimensions. Rome de métnpbysique et de morale 11, 1903 , 281-301: 407-429. Retomado in Poincaré 1905 (cap. 3: La notion d'espace, e 4: L'espace et ses trois dimensions), 1970, pp. 55-76, 77-100.

POINCARÉ, Henri 1905 a. La valcur de la science, Flammarion, Paris, 1905 : reed. 1970.

REICHENB $\Lambda$ CH, Hans 1949. The plilosophical significance of the theory of relativity, in Schilpp 1949, pp. 289.311.

REICHENBACH, Hans 1951. The rise of scientific plsilosoplry, University of California Press, Berkeley,

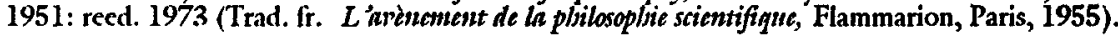

REICHENBACH, Hans 1978. Selcted nritings, ed. by Robert S. Cohen and Maria Reichenbach, 2 vols., Reidel, Dordrecht, 1978.

SCHILPP, Paul-Arthur (ed.) 1949. Albert Einstein: philosopher scientist, The library of living philosophers, Open Court, Lassalle (III), 1949. Reed. 1970.

SCHILICK, Moritz 1918. Algemcime Erkcnntmislehre. Naturvissenschaftliche Monographien und Lehrbiicher I, Berlin. $2^{\mathrm{a}}$ ed. rev., 1925: reed., Frankfurt am Main, 1979 (Trad. ing. sobre a $2^{\mathrm{a}}$ edição alemä de Albert E. Blumberg. Gencral theory of knowledge, Library of exact philosophy, New York, 1974).

SCHLICK. Moritz 1930. Gibt es ein materiales Apriori? (conferência de 1930), in Wissenschaftlischor Jahrestlericlst der Philosoplischen Gesellschaft and der Uniremitit za Wien-Ontsgrmppe Wien der KantGescllsclunft fir das T'trcinjohn 1931-1932, Wien, 1932, pp. 55-65 (Trad. ing. de Wilfrid Sellars, Is there a factual a priori?, in Schlick 1979-1980, v. 2, pp. 161-70).

SCIHLICK, Moritz 1979-1980. Philosoplsical papers, ed. by Mulder, H. L. and van de Velde-Schlick, B. F. B. (Trad. do alemāo, 2 vols., Reidel. Dordrecht, 1979-1980).

STEGMÜLLER, Wolfgang 1973. Probleme und Resutate der Wissenschaftstheoric und Analytischen Philosoplic. Band II: Thcoric und Ehrfalmrung. Zneiter Halbband: Theotienstmikturen uns Theoriendynamik. Springer-Verlag, Heidelberg, 1973 (Trad. esp. de C. Ulises Moulines, Estructura y dinamica de teorias, Ariel, Barcelona, 1983).

STEGMÜLLER, Wolfgang 1979. T7ıe structuralist viem of theories. A posible analogue of the Bourbaki programme in physical scictice, Springer-Verlag, Berlim, 1979.

\section{Resumo}

O trabalho desenvolve as implicações da idéia de que quando uma teoria atinge um estágio abstrato de formalizaçāo, comoé o caso de teorias físicas, da mecânica quântica, o significado de seus conceitos e proposiçōes, objetivos para representação e inteligibilidade do mundo físico (realidade física em qualquer de suas acepçóes) é obtido a partir da própria teoria. Em síntese, "é a própria que dita o significado de suas proposiçőes", segundo Einstein e Heisenberg.

Em seguida apresenta uma análise do significado de 'teoria formalizada' para o caso das ciências de contcúdo empírico como a física, concluindo que a acepção adotada não pode ser reduzida a um 'formalismo interpretado' nos moldes aceitos pelos elementos do Círculo de Viena. Aspectos dinâmicos das teorias são também discutidos.

Finalmente, a partir das consideraçóes acima, é introduzido o conceito de 'endo-referência' e discuridas as suas conexóes com o conceito kantiano de sintético a priori.

\section{Abstract}

The paper develops epistemological implications of the idea that, when a theory is in state of abstract formalization (as to-day physical theory, quantum physics for instance is), the 
meaning of its concepts and propositions, which are aiming at the representation and intelligibility of the external physical world is however to be taken from within the theory irself. "Ir is the theory itself which dictates the physical significance of its propositions" in the words of Heisenberg and Einstein. It contains also the analysis of what is meant by

"formalized theory" for a science with empirical content as physics and concludes that it cannot be reduced to a mere "interpreta formalism" in the sense of logical impiricism.

Finaly it works on the sense of endoreference connctions with a kantian concept of a priori synthetic.

Michsl Paty é professor do Centro Nacional de Pesquisa Científica (CNRS), da França. Especialista em história e filosofia da ciência, fez palestras no IEA-USP em 1990 sobre " Einstein, física, matemática e filosolia".

Tradução de Belkiss Jasinevicius Rabello. Revisão técnica de Lafayette de Moraes e Edelcio Gonçalves de Souza. O original em francês encontra-se à disposição do leitor no IEA para eventual consulta. 